\title{
Primary pulmonary plasmacytoma mimicking lung cancer diagnosed on endobronchial ultrasound (EBUS)-guided biopsy
}

\author{
Usman Maqsood, Hefin Jones, Daniel Gey van Pittius, Mohammed Haris
}

Royal Stoke University Hospital, Stoke on Trent, UK

\section{Correspondence to} Dr Usman Maqsood, drusmanmaqsood@yahoo.com

Accepted 2 June 2016

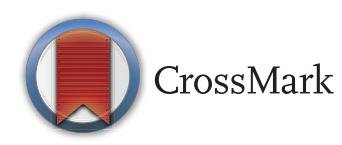

To cite: Maqsood $U$, Jones $\mathrm{H}$, Gey van Pittius D, et al. BMJ Case Rep Published online: [please include Day Month Year] doi:10.1136/bcr-2016215785

\section{DESCRIPTION}

A 77-year-old woman presented with progressive breathlessness on exertion. Chest radiograph showed a smooth right apical mass and CT of the chest confirmed a bilobed, well-defined right apical mass (figure 1). Positron emission tomography-CT showed a right apical soft tissue mass with marked fluorodeoxyglucose uptake (standardised uptake value max 8.6) with chest wall and likely mediastinal invasion (figure 2). The patient was referred for endobronchial ultrasound (EBUS) and a right paratracheal mass was noted; a $21 \mathrm{G}$ needle was used to aspirate the lesion and the histology was

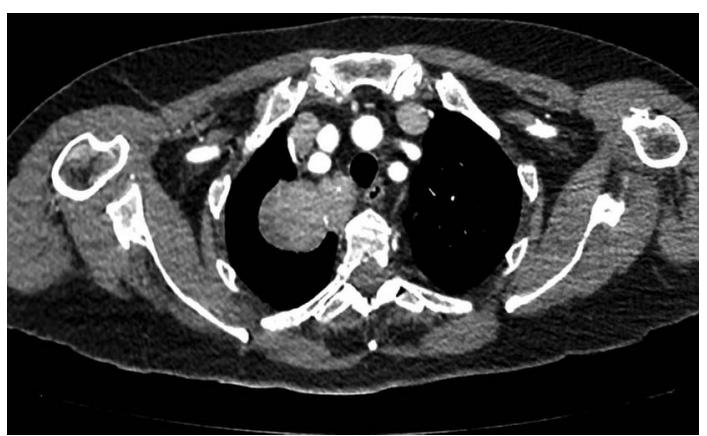

Figure 1 Axial slice of arterial phase contrast-enhanced $\mathrm{CT}$, demonstrating avid-enhancement of a bilobed soft tissue mass, arising within the superior mediastinum, adjacent to vertebrae.

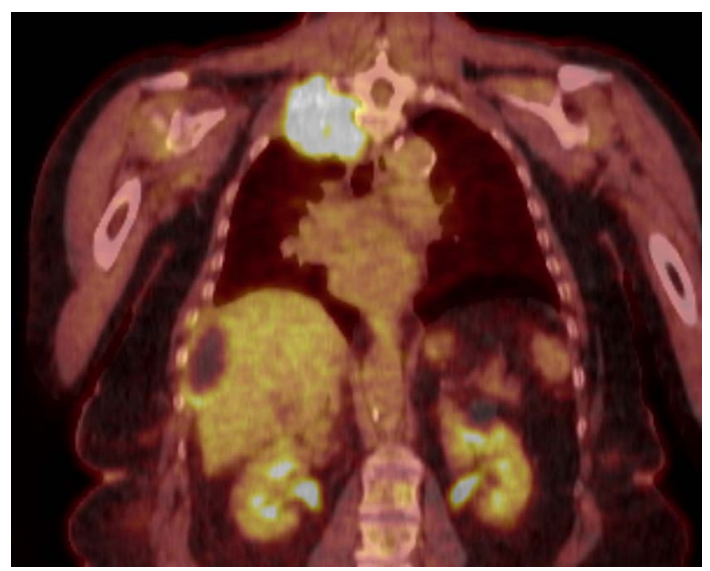

Figure 2 Fluorodeoxyglucose (FDG) positron emission tomography/CT, coronal fused images, demonstrating avid FDG uptake (standardised uptake value max 8.6) within the previously seen right apical mass. Incidental note is made of photopenia within the liver, representing a benign cyst. consistent with plasmacytoma (figure 3). Haematological staging investigations showed no evidence of systemic multiple myeloma. The patient was treated with radical radiotherapy.

Multiple myeloma is a systemic monoclonal plasma cell neoplasia primarily involving the bone marrow. A minority $(<5 \%)$ of patients present with solitary bone plasmacytoma or, less commonly, with solitary extramedullary plasmacytoma. Thoracic involvement is very rare; it usually presents as a lung mass and, in some cases, with endobronchial infiltration. ${ }^{1}$ Diagnosis on routine imaging can be challenging and a surgical biopsy may be required. ${ }^{3}$ To the best of our knowledge, this is the first case of primary pulmonary plasmacytoma diagnosed on EBUS-guided sampling.

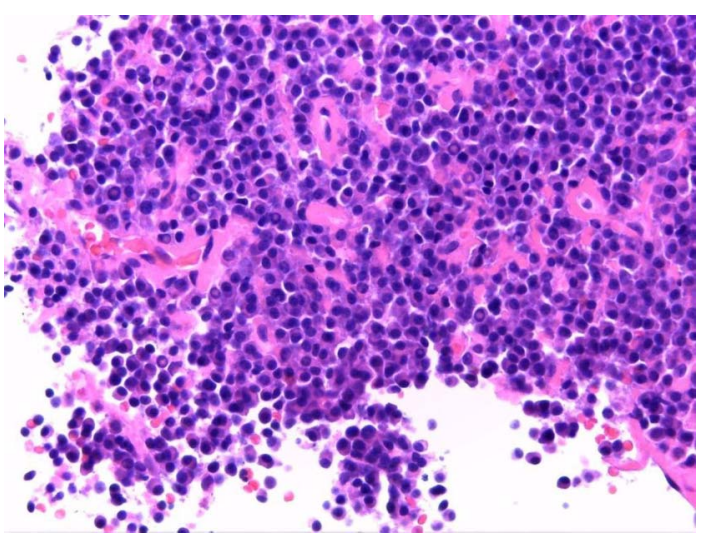

Figure 3 Histology image showing a medium sized atypical plamacytoid population of cells with extracellular and perivascular amyloid deposition.

\section{Learning points}

- Primary pulmonary plasmacytoma should be considered in the differential diagnosis of lung masses.

- Endobronchial ultrasound-guided biopsy should be taken into account as first line investigation to gain biopsy sample.

Contributors UM wrote the initial manuscript. $\mathrm{HJ}$ reviewed and wrote the radiological descriptions. DGvP contributed towards the histopathology. MH performed the EBUS biopsy and reviewed the final manuscript. The case was managed and manuscript reviewed by all the authors.

Competing interests None declared.

Patient consent Obtained. 
Provenance and peer review Not commissioned; externally peer reviewed.

\section{REFERENCES}

1 Galieni P, Cavo M, Pulsoni A, et al. Clinical outcome of extramedullary plasmacytoma. Haematologica 2000;85:47-51.
2 Goździuk K, Kedra M, Rybojad P, et al. A rare case of solitary plasmacytoma mimicking primary lung tumor. Ann Thorac Surg 2009;87: e25-6.

3 Durris N, Rosnet $\mathrm{G}$, Clemenson A, et al. Characteristics and management of tracheobronchial extramedullary plasmacytomas. J Bronchology 2002; 9:186-92.

Copyright 2016 BMJ Publishing Group. All rights reserved. For permission to reuse any of this content visit http://group.bmj.com/group/rights-licensing/permissions.

BMJ Case Report Fellows may re-use this article for personal use and teaching without any further permission.

Become a Fellow of BMJ Case Reports today and you can:

- Submit as many cases as you like

- Enjoy fast sympathetic peer review and rapid publication of accepted articles

- Access all the published articles

- Re-use any of the published material for personal use and teaching without further permission

For information on Institutional Fellowships contact consortiasales@bmjgroup.com

Visit casereports.bmj.com for more articles like this and to become a Fellow 